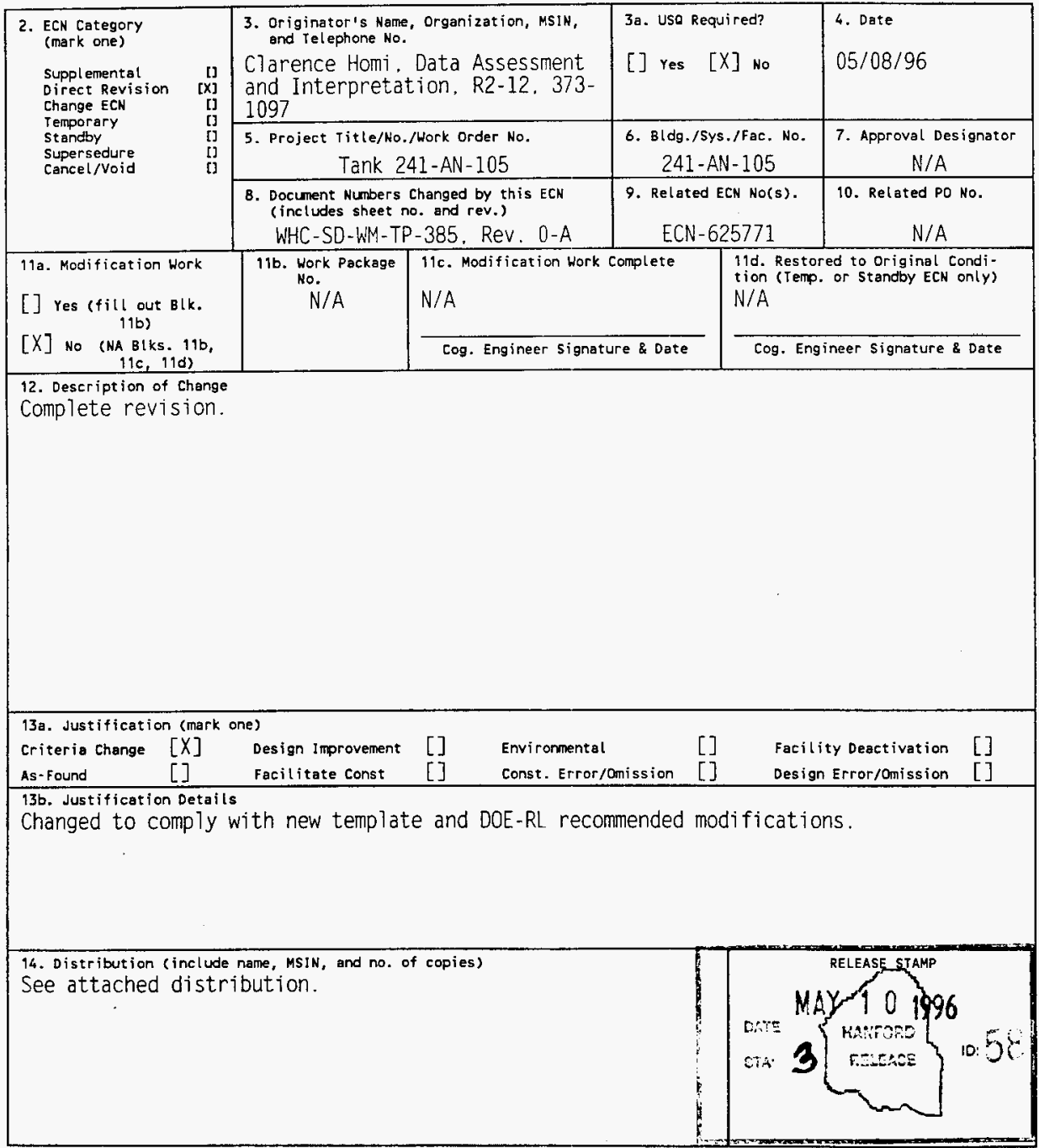




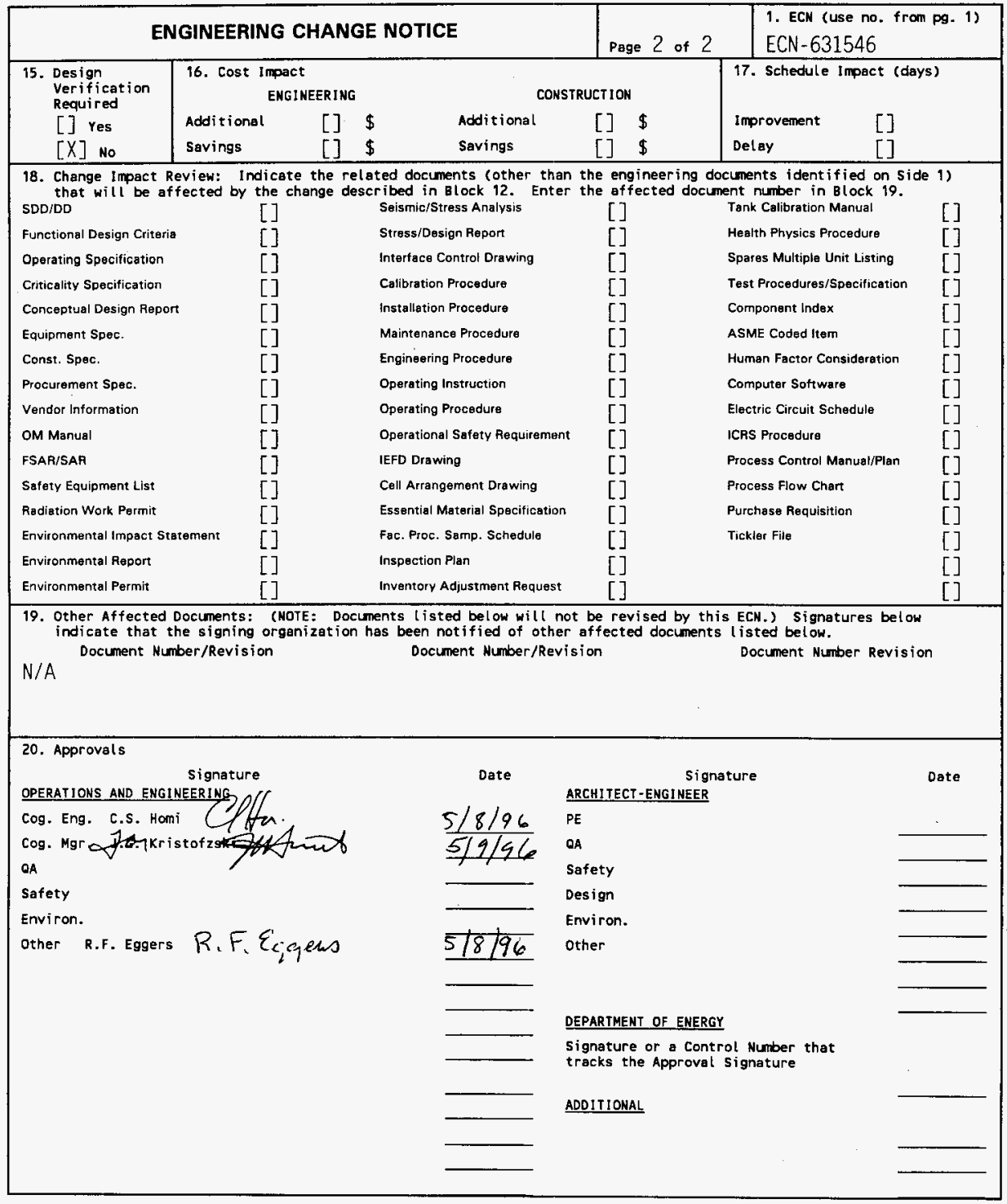




\title{
Tank 241-AN-105 Tank Characterization Plan
}

\author{
C. S. Homi
}

Westinghouse Hanford Company, Richland, WA 99352

U.S. Department of Energy Contract DE-AC06-87RL10930

$\begin{array}{lll}\text { EDT/ECN: } & \text { ECN }-631546 & \text { UC: } 2070 \\ \text { Org Code: } & 79200 & \text { Charge Code: } \\ \text { B\&R Code: } & \text { EW } 3120074 & \text { Tota1 Pages: } 9\end{array}$

Key Words: Characterization. General Safety Issues, Specific Safety Issues, Information Requirements. Schedule

Abstract: This document is a plan that identifies the information needed to address relevant issues concerning short-term and long-term storage and long-term management of double-shell tank 241-AN-105.

TRADEMARK DISCLAIMER. Reference herein to any specific comercial product, process, or service by trade name, trademark, manufacture $r$, or otherwise, does not necessarily constitute or imply its endorsenent, reconmendation, or favoring by the United States Government or any agency thereof or its contractors or subcontractors.

Printed in the United States of America. To obtain copies of this document, contact: UHC/BCS Document Control Services, P.0. Box 1970, Mailstop H6-08, Richland WA 99352, Phone (509) 372-2420; Fax (509) 376-4989.
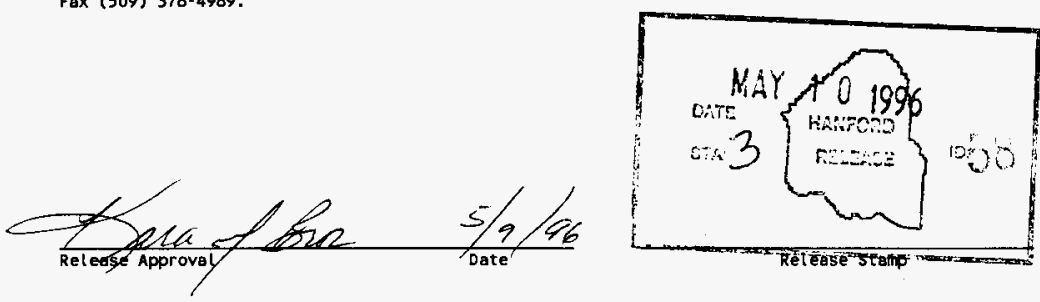

\section{Approved for Public Release}




\section{RECORD OF REVISION}

(1) Document Number

(2) Title

TANK 241-AN-105 TANK CHARACTERIZATION PLAN

CHANGE CONTROL RECORD

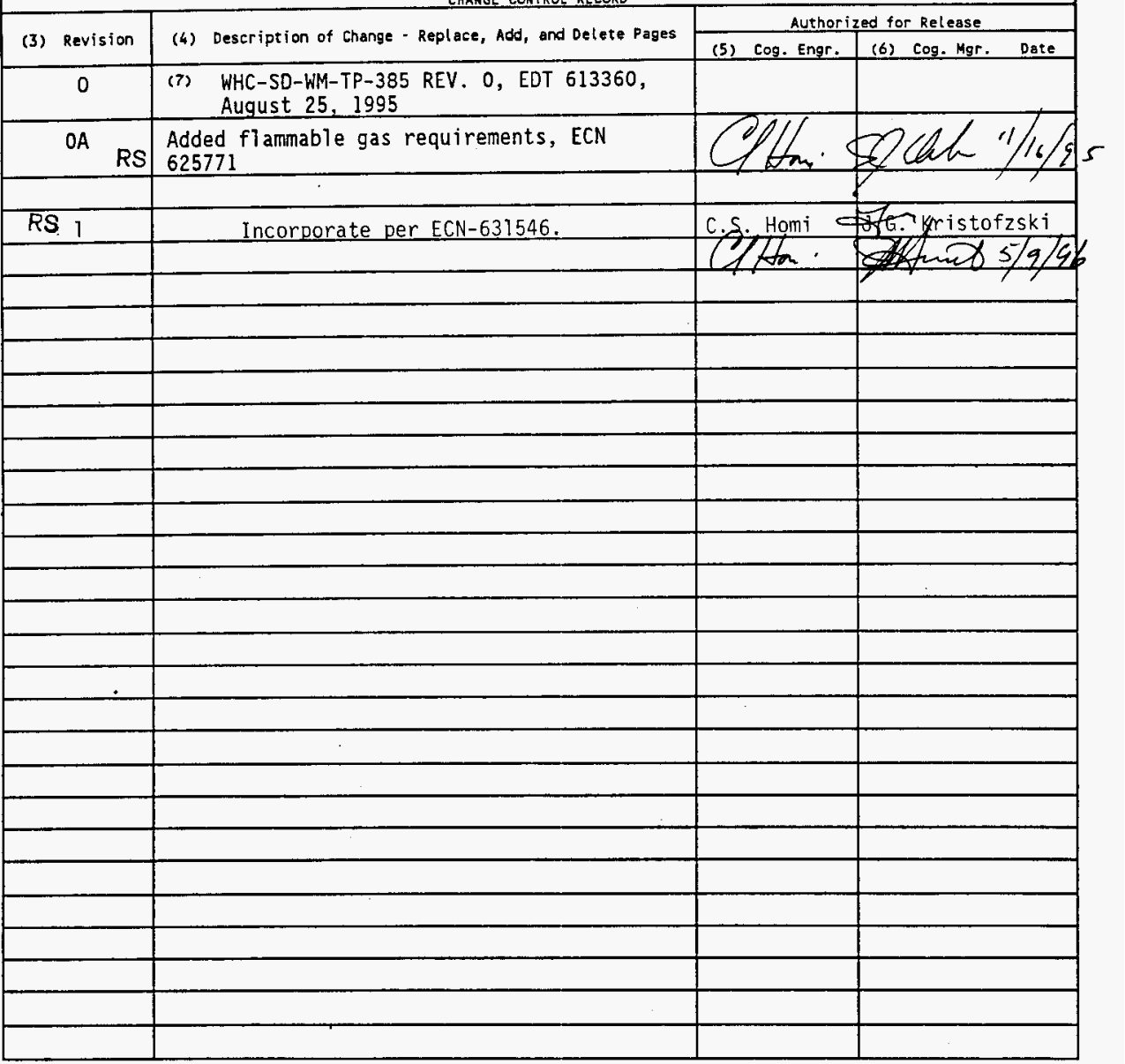


WHC-SD-WM-TP-385

Revision 1

UC-2070

\section{Tank 241-AN-105 Tank Characterization Plan}

R. F. Eggers

Westinghouse Hanford Company

Date Published

May 1996

Prepared for the U.S. Department of Energy Office of Environmental Restoration and Waste Management

\section{(20) Westinghouse P. B. Box 1990 Hanford Company Richand, wasthingon}

Management and Operations Contractor for the

U.S. Department of Energy under Contract DE-AC06-87RL10930

Approved for Public Release 
WHC-SD-WM-TP-385, REV 1

TABLE OF CONTENTS

1.0 INTRODUCTION . . . . . . . . . . . . . . . . . . . . . 1

2.0 PROGRAM ELEMENTS REQUIRING INFORMATION FOR TANK 241-AN-105 . . . . 1

2.1 GENERAL SAFETY ISSUES . . . . . . . . . . . . . . . . . . 1

2.2 SPECIFIC SAFETY ISSUES . . . . . . . . . . . . . . . . 2

2.2.1 Ferrocyanide .................. 2

2.2.2 Organic .................. 2

2.2.3 High Heat .................... 2

2.2.4 Flammable Gas ................... 2

2.2 .5 Vapor.................. . . 2

2.2.6 Criticality................ 2

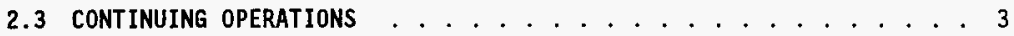

2.3.1 Compatibility/Stabilization ............ 3

2.3.2 Evaporator ................ 3

2.4 DOUBLE-SHELL TANK WASTE ANALYSIS PLAN . . . . . . . . . . . 3

2.5 DISPOSAL . . . . . . . . . . . . . . . . . . 3

2.5.1 Retrieval .................... 3

2.5.2 Pretreatment/Vitrification .......... 3

2.6 HISTORICAL MODEL EVALUATION . . . . . . . . . . . . . . 3

3.0 HOW INFORMATION WILL BE OBTAINED .................. 3

4.0 PRIORITY OF INFORMATION REQUIREMENTS . . . . . . . . . . . . . . . . 4

5.0 WHEN INFORMATION WILL BE AVAILABLE ................ 4

6.0 REFERENCES ....................... . . 5

\section{LIST OF TABLES}

4-1 Integrated DQO Requirements and Priorities ........... 4 


\subsection{INTRODUCTION}

This Tank Characterization Plan (TCP) identifies the information needed to address relevant issues concerning short-term and long-term safe storage and long-term management of double shell tank 24l-AN-105 (AN-105). It should be understood that the various needs and issues surrounding tank AN-105 are evolving as new information about the tank is uncovered. As a result of this progression, this ICP addresses only the issues that, to this date, have been identified. It is expected that deviations from this plan may occur as additional issues or needs arise which impact the management of tank AN-105. As necessary, this TCP be revised to reflect those changes or deviations. This plan reflects the best information available as of May 1996.

Tank AN-105 was constructed from 1978 to 1980 and entered into service in September 1981. The tank received non-complexed waste until November, 1982. From December 1982 until the second quarter of 1985 , when waste reception ceased, the tank received double shel1 slurry feed from tanks 241-AW-102 and 241-AN-104. Tank AN-105 is currently inactive and holds concentrated waste. In January 1991 the tank was added to the Flammable Gas Watch List. Slight level changes are attributed to slurry growth as a result of gas generation (Brevick et al. 1995).

Tank AN-105 currently contains $4269 \mathrm{~kL}$ (1128 kgal) of waste, which is equivalent to $1042 \mathrm{~cm}(410 \mathrm{in})$ of waste as measured from the baseline of the tank (Hanlon 1996).

This tank is on the Flammable Gas Watch List.

Near-term sampling and analysis activities are focused on either verifying or changing the watch list tank status, and identifying any new safety issues. Should any safety issues be identified, additional analysis will occur consistent with the identified issue.

In addition to the resolution of the safety issues, it is intended that all tank waste will be subject to pretreatment and retrieval to prepare for final storage or disposal. Presently, these long-range plans have yet to be fully identified and are, therefore, not included in this document.

\subsection{PROGRAM ELEMENTS REQUIRING INFORMATION FOR TANK 241-AN-105}

This section identifies the various program elements, and identifies which of these programs require characterization data from tank AN-105.

\subsection{GENERAL SAFETY ISSUES}

The Tank Safety Screening Data Quality Objective (Dukelow et al. 1995) describes the sampling and analytical requirements that are used to screen waste tanks for unidentified safety issues. Analytical requirements for the safety screening of a tank are energetics, total alpha activity, moisture content, density and flammable gas concentration. 
WHC-SD-WM-TP-385, REV 1

\subsection{SPECIFIC SAFETY ISSUES}

\subsubsection{Ferrocyanide}

This tank is not on the Ferrocyanide Watch List; therefore, no information needs are currently identified for this program element.

\subsubsection{Organic}

This tank is not on the Organic Watch List; therefore, no information needs are currently identified for this program element.

\subsubsection{High Heat}

This tank is not on the High Heat Watch List; therefore, no information needs are currently identified for this program element.

\subsubsection{Flammable Gas}

This tank is on the Flammable Gas Watch List. The applicable data quality objective (DQO) for this safety issue is: Flammable Gas Safety Program: Data Requirements for Core Sample Analysis Developed through the Data Quality objectives Process (McDuffie 1995).

\subsubsection{Vapor}

A11 177 underground tanks must be vapor-sampled for organic solvent screening as per Recommendation 93-5 Implementation Plan (DOE-RL 1996). Some tanks may require additional vapor sampling due to other program needs. These tanks may be classified into four categories: (1) those tanks which are to be rotary mode core sampled (as a consequence of the rotary sampling system exhauster permit requirements); (2) tanks on the Organic or Ferrocyanide Watch Lists; (3) tanks in C farm; and (4) tank 24l-BX-104, due to vapor exposure. Information needs must satisfy Data Quality Objectives for Tank Hazardous Vapor Safety Screening (Osborne and Buckley 1995), and for rotary mode only, Rotary Core Vapor Sampling Data Quality Objective (Price 1994), and Data Quality Objective for Regulatory Requirements for Hazardous and Radioactive Air Emissions Sampling and Analysis (Mulkey and Marki17ie 1995) as amended by Status of the Current Understanding of the Toxic Air Pollutants (TAPS) and Hanford Tank Farm Vapor Space Characterization; Recommended Path Forward and Justification for Cont inued RMCS Exhauster Operations (Laws 1996).

\subsubsection{Criticality}

No information separate from that for the general safety issue of tank AN-105 are currently identified for this program element. However, if the general safety screening of tank AN-105 identifies a potential criticality concern, analyses for fissile materials and neutron sorbers and poisons will be performed as identified in the safety screening $D Q 0$. 
WHC-SD-WM-TP-385, REV 1

\subsection{CONTINUING OPERATIONS}

\subsubsection{Compatibility/Stabilization}

This section does not apply to tank AN-105.

\subsubsection{Evaporator}

This section does not apply to tank AN-105.

\subsection{DOUBLE-SHELL TANK WASTE ANALYSIS PLAN}

Requirements for double-shell waste analyses are found in Double-Shell Tank Waste Analysis Plan (Mulkey and Jones 1995). This plan uses the compatibility (Fowler 1995) and safety screening (Dukelow et a1. 1995) DQ0s as the basis for identifying data requirements and criteria for the safe storage and mixing of wastes.

\subsection{DISPOSAL}

\subsubsection{Retrieval}

Current retrieval needs (Bloom and Nguyen 1995) do not call for test samples to be taken from tank AN-105.

\subsubsection{Pretreatment/Vitrification}

Tank AN-105 has not been identified as a bounding tank for pretreatment/ disposal process development strategy (Kupfer et al. 1995). All tanks were prioritized using the pretreatment strategy in the Tank Waste Characterization Basis (Brown et al. 1995) document and a portion of archive sample material could be used for pretreatment testing if available. The Strategy does not require any specific analyses to be done on the samples.

\subsection{HISTORICAL MODEL EVALUATION}

Bounding tanks and data requirements for historical model evaluations are found in Historical Model Evaluation Data Requirements (Simpson and McCain 1995). Tank AN-105 is not identified as a primary bounding tank for historical model evaluations.

\subsection{HOW INFORMATION WILL BE OBTAINED}

The number of samples required to characterize a tank is a function of waste heterogeneity and the desired confidence to make a correct decision. As directed by the safety screening $\mathrm{DQO}$, if inadequate information exists to determine an appropriate number of samples, two vertical profiles will be obtained. These vertical profiles may be obtained using core, auger (for shallow tanks), or grab samples. If analysis of these profiles reveals that 
WHC-SD-WM-TP-385, REV 1

additional profiles are necessary to meet data needs, more sample profiles wi11 be requested.

\subsection{PRIORITY OF INFORMATION REQUIREMENTS}

Push mode core sampling is scheduled for completion May 1996. Vapor sampling has not been scheduled as of April 1996 (Stanton 1996). Refer to Table 4-1 for the current DQO requirements and planned sampling and analytical requirements.

Table 4-1: Integrated DQO Requirements and Priorities

\begin{tabular}{||l|l|l|l|}
\hline $\begin{array}{l}\text { Sampling } \\
\text { Event }\end{array}$ & \multicolumn{1}{|c|}{ Applicable Issues } & Sampling Requirements & Analytical Requirements \\
\hline $\begin{array}{l}\text { Push Mode } \\
\text { Core } \\
\text { Sampling }\end{array}$ & $\begin{array}{l}\text {-Safety Screening DQO } \\
\text {-Flammable Gas DQO }\end{array}$ & $\begin{array}{l}\text { Core samples from 2 } \\
\text { risers separated } \\
\text { radially to the } \\
\text { maximum extent } \\
\text { possible }\end{array}$ & $\begin{array}{l}\text { Flammability, Energetics, } \\
\text { Moisture, Total alpha } \\
\text { activity, Anions, Meta1s, } \\
\text { Radionuclides, Density, } \\
\text { Physical properties, pH, } \\
\text { Total Organic Carbon, } \\
\text { Total Inorganic Carbon, } \\
\text { Cr(VI) }\end{array}$ \\
\hline Vapor & $\begin{array}{l}\text {-Organic Solvent Layer } \\
93-5 \text { Vapor Issue } \\
\text {-Hazardous Vapor DQO }\end{array}$ & $\begin{array}{l}\text { Steel canisters, } \\
\text { Triple sorbent Traps, } \\
\text { Sorbent Trap Systems. }\end{array}$ & $\begin{array}{l}\text { Frganic Vapors } \\
\text { Permanent Gases }\end{array}$ \\
\hline
\end{tabular}

* Consult each applicable DQO in force at the time for sampling and analytical requirements.

\subsection{WHEN INFORMATION WILL BE AVAILABLE}

According to Stanton (1996) data are expected to be available from the push mode core sampling event for tank AN-105 in September 1996. This time may be altered if the sampling schedule changes. 


\section{WHC-SD-WM-TP-385, REV I}

\subsection{REFERENCES}

Bloom, G. R. and Q. H. Nguyen, 1995, Characterization Data Needs for Development, Design and Operation of Retrieval Equipment Developed Through the Data Quality Objective Process, WHC-SD-WM-DQ0-008, Rev. 0, Westinghouse Hanford Company, Richland, Washington.

Brevick, C. H., L. A. Gaddis, and W. W. Pickett, 1995, Historical Tank Content Estimate for the Southeast Quadrant of the Hanford 200 Areas, WHC-SD-WM-ER-350, Rev. 0, Westinghouse Hanford Company, Richland, Washington.

Brown, T. M., S. J. Eberlein, and T. J. Kunthara, 1995, Tank Waste Characterization Basis, WHC-SD-WM-TA-164, Rev. 1, Westinghouse Hanford Company, Richland, Washington.

DOE-RL, 1996, Recommendation 93-5 Implementation Plan, DOE/RL-94-0001, Rev. 1, U.S. Department of Energy, Richland, Washington.

Dukelow, G. T., J. W. Hunt, H. Babad, and J. E. Meacham, 1995, Tank Safety Screening Data Quality Objective, WHC-SD-WM-SP-004, Rev. 2, Westinghouse Hanford Company, Richland, Washington.

Fowler, K.D., 1995, Data Quality Objectives for Tank Farm Waste Compatibility Program, WHC-SD-WM-DQO-001, Rev. 1, Westinghouse Hanford Company, Richland, Washington.

Hanlon, B.M., 1996, Waste Tank Summary Report for the Month Ending January 31, 1996, WHC-EP-0182-94, Westinghouse Hanford Company, Richland, Washington.

Kupfer, M. J., W. W. Schultz, and J. T. Slankas, 1995, Strategy for Sampling Hanford Site Tank Wastes for Development of Disposal Technology, WHC-SD-WM-TA-154, Rev. 1, West inghouse Hanford Company, Richland, Washington.

Laws, G. L., 1996, Status of the Current Understanding of the Toxic Air Pollutants (TAPS) and Hanford Tank Farm Vapor Space Characterization; Recommended Path Forward and Justification for Continued RMCS Exhauster Operations, (telephone conference memorandum, 01830-96-022, to Distribution, March 8) Westinghouse Hanford Company, Richland, Washington.

McDuffie, N. G., 1995, Flammable Gas Tank Safety Program: Data Requirements for Core Sample Analysis Developed Through the Data Quality Objectives Process, WHC-SD-WM-DQ0-004, Rev. 2, Westinghouse Hanford Company, Richland, Washington.

Mulkey, C.H., and K. D. Markillie, 1995, Data Quality Objective for Regulatory Requirements for Hazardous and Radioactive Air Emissions Sampling and Ana7ysis, WHC-SD-WM-DQ0-021, Rev. 0, Westinghouse Hanford Company, Richland, Washington. 


\section{WHC-SD-WM-TP-385, REV 1}

Mulkey, C. H., and J. M. Jones, 1995, Double-Shel7 Tank System Waste Analysis P7an, WHC-SD-WM-EV-053, Rev 3, Westinghouse Hanford Company, Richland, Washington.

Osborne, J. W., and L. L. Buckley, 1995, Data Quality Objectives for Tank. Hazardous Vapor Safety Screening, WHC-SD-WM-DQO-002, Rev. 2, West inghouse Hanford Company, Richland, Washington.

Price, D. N., 1994, Rotary Core Vapor Sampling Data Quality Objective, WHC-SD-WM-SP-003, Rev. 0, Westinghouse Hanford Company, Richland, Washington.

Simpson, B. C., and D. J. McCain, 1995, Historical Model Evaluation Data Requirements, WHC-SD-WM-DQ0-018, Rev. OA, Westinghouse Hanford Company, Richland, Washington.

Stanton, G. A., 1996, Baseline Sampling Schedule, Change 96-02, (internal memo 75610-96-06, to Distribution, Apri7 17), Westinghouse Hanford Company, Richland, Washington. 